Article

\title{
Preoperative Axillary Ultrasound versus Sentinel Lymph Node Biopsy in Patients with Early Breast Cancer
}

\author{
Dalia Rukanskienè ${ }^{1, * \mathbb{D}}$, Vincentas Veikutis ${ }^{2}$, Eglè Jonaitienè ${ }^{1}$, Milda Basevičiūtè ${ }^{3}$, \\ Domantas Kunigiškis ${ }^{3}$, Renata Paukštaitienè ${ }^{4}$, Daiva Čepulienè ${ }^{5}$, Lina Poškienè ${ }^{6}$ and \\ Algirdas Boguševičius ${ }^{5}$
}

1 Department of Radiology, Faculty of Medicine, Medical Academy, Lithuanian University of Health Sciences, LT-50161 Kaunas, Lithuania; drebule@hotmail.com

2 Institute of Cardiology, Faculty of Medicine, Medical Academy, Lithuanian University of Health Sciences, LT-50162 Kaunas, Lithuania; vincentas.veikutis@lsmuni.lt

3 Faculty of Medicine, Medical Academy, Lithuanian University of Health Sciences, LT-44307 Kaunas, Lithuania; mbasev@gmail.com (M.B.); domantas.ku@gmail.com (D.K.)

4 Department of Physics, Mathematics and Biophysics, Faculty of Medicine, Medical Academy, Lithuanian University of Health Sciences, LT-44307 Kaunas, Lithuania; renata.paukstaitiene@gmail.com

5 Department of Surgery, Faculty of Medicine, Medical Academy, Lithuanian University of Health Sciences, LT-50161 Kaunas, Lithuania; daiva.cepuliene@yahoo.com (D.Č.);

algirdas.bogusevicius@kaunoklinikos.lt (A.B.)

6 Department of Pathological Anatomy, Faculty of Medicine, Medical Academy, Lithuanian University of Health Sciences, LT-50161 Kaunas, Lithuania; lina_poskiene@yahoo.com

* Correspondence: dalia.artmoniene@gmail.com; Tel.: +370-68-219472

Received: 29 January 2020; Accepted: 11 March 2020; Published: 13 March 2020

check for updates

Abstract: Background and objectives: With improved diagnostic means of early breast cancer, the percentage of cases with metastasis in axillary lymph nodes has decreased from 50-75\% to 15-30\%. Lymphadenectomy and sentinel lymph node biopsy are not treatment procedures, as they aim at axillary nodal staging in breast cancer. Being surgical interventions, they can lead to various complications. Therefore, recently much attention has been paid to the identification of non-invasive methods for axillary nodal staging. In many countries, ultrasound is a first-line method to evaluate axillary lymph node status. The aim of this study was to evaluate the prognostic value of ultrasound in detecting intact axillary lymph nodes and to assess the accuracy of ultrasound in detecting a heavy nodal disease burden. The additional objective was to evaluate patients' and tumor characteristics leading to false-negative results. Materials and Methods: A total of 227 women with newly diagnosed pT1 breast cancer were included to this prospective study conducted at the Breast Surgery Unit, Clinic of Surgery, Hospital of Lithuanian University of Health Sciences Kauno Klinikos, between May 1, 2016, and May 31, 2018. All patients underwent preoperative axillary ultrasound examination. Ultrasound data were compared with the results of histological examination. The accuracy and true-negative rate of ultrasound were calculated. The reasons of false-negative results were analyzed. Results: Of the 189 patients who had normally appearing axillary lymph nodes on preoperative ultrasound (PAUS-negative), 173 (91.5\%) patients were also confirmed to have intact axillary lymph nodes (node-negative) by histological examination after surgery. The accuracy and the negative predictive value of ultrasound examination were $84.1 \%$ and $91.5 \%$, respectively. In $\geq 3$ node-positive cases, the accuracy and the negative predictive value increased to $88.7 \%$ and $98.3 \%$, respectively. In total, false-negative results were found in $8.5 \%$ of the cases $(n=16)$; in the PAUS-negative group, false-negative results were recorded only in $1.6 \%$ of the cases $(n=3)$. The results of PAUS and pathological examination differed significantly between patients without and with lymphovascular invasion (LV0 vs. LV1, $p<0.001$ ) as well as those showing no human epidermal growth factor receptor 2 (HER2) expression and patients with weakly or strongly expressed HER2 (HER2(0) vs. HER2(1), 
$p=0.024)$. Paired comparisons revealed that the true-negative rate was significantly different between the LV0 and LV1 groups ( $91 \%$ vs. $66.7 \%, p<0.05$ ), and the false-negative rate was statistically significant different between the HER2(0) and HER2(1) groups (10.5\% vs. $1.2 \%, p<0.05)$. Evaluation of other characteristics showed both the groups to be homogenous. Conclusions: Negative axillary ultrasound excluded axillary metastatic disease in $91.5 \%$ of the patients. PAUS had an accuracy of $88.7 \%$ in detecting a heavy nodal disease burden. With the absence of lymphovascular invasion (LV0), we can rely on PAUS examination that axillary lymph nodes are intact (PAUS-negative), and this patients' group could avoid sentinel lymph node biopsy. Patients without HER2 expression are at a greater likelihood of false-negative results; therefore, the findings of ultrasound that axillary lymph nodes are intact (PAUS-negative results) should be interpreted with caution.

Keywords: breast cancer; axillary lymph nodes; ultrasound; lymphadenectomy; sentinel lymph node biopsy

\section{Introduction}

Tumor size and axillary nodal status are the most important prognostic factors for breast cancer in predicting overall and disease-free survival [1]. The risk of developing metastasis mainly depends on tumor biological characteristics [2]. Recently, the influence of biological tumor characteristics on the strategy of adjuvant treatment is increasing, and the value of estimation of axillary lymph node status is decreasing [2].

With emerging breast cancer screening programs, more frequently breast cancer is diagnosed at its early stage, and axillary nodal negative disease accounts for $70 \%$ to $85 \%$ of cases [3]. Today, all patients undergo a sentinel lymph node biopsy (SLNB) in order to determine axillary nodal status; however, the majority of patients do not need this surgical intervention [4-7]. Considering that both SLNB and lymphadenectomy (axillary lymph node dissection, ALND) are not treatment procedures, but are performed with the aim of tumor staging, recently much attention has been given to the identification of non-invasive procedures for diagnostic purposes [8]. Preoperative axillary ultrasound (PAUS) is a first-line method to evaluate axillary nodal status [9-11]. Currently, there are two ongoing clinical studies (SOUND and INSEMA) that aim at evaluating differences in overall survival, disease-free survival, and quality of life in women with breast cancer by dividing them into two groups: women who underwent SLNB and women who had clinically and sonographically tumor-free axillary lymph nodes $(\mathrm{c} / \mathrm{sN})$ and did not undergo SLNB $[12,13]$. It is assumed that preoperative ultrasound examination allows the identification of patients with clinically important axillary node lesions (metastases in $\geq 3$ lymph nodes), and if axillary lymph nodes appear to have normal appearance on ultrasound (PAUS-negative), SLNB could be avoided.

The aim of our study was to determine the prognostic value of PAUS while evaluating that axillary lymph nodes are tumor free and to assess the accuracy of PAUS while identifying a heavy nodal disease burden ( $\geq 3$ metastases in axillary lymph nodes). An additional objective was to determine a false-negative rate in predicting any nodal positivity and a heavy nodal disease burden as well as to examine what clinicopathological factors were associated with this.

\section{Materials and Methods}

This prospective study enrolled women with newly diagnosed breast cancer, who were treated in the Breast Surgery Unit, Clinic of Surgery, Hospital of Lithuanian University of Health Sciences Kauno Klinikos, between May 1, 2016, and May 31, 2018. The study was approved by Kaunas Regional Biomedical Research Ethics Committee (permission No. BE-2-25, Approved on July 18, 2016). 
The exclusion criteria were as follows: (1) patient's refusal to participate; (2) neoadjuvant chemotherapy; and (3) and recurrent breast cancer. Of the 328 patients examined, 227 women with pT1 breast cancer were enrolled in this study. Bilateral breast cancer was analyzed as two separate cases.

One day before surgery, sentinel lymph nodes were marked by a $0.2 \mathrm{~mL}$ periareolar injection of $50 \mathrm{MBq}$ of $99 \mathrm{mTC}-\mathrm{Nanocoll}$. On the skin, the location of the sentinel lymph node (SLN) was detected using a 2010 Philips BrightView Gamma Camera.

On the day of surgery, all patients underwent repeated PAUS of the targeted areas of SLNs. PAUS was performed using an Acuson S2000 ultrasound unit with a $14 \mathrm{MHz}$ linear Siemens transducer. The PAUS examination assessed whether lymph nodes were normally appearing (PAUS-negative) or were suspicious (PAUS-positive). The signs of PAUS-negative axillary lymph node were as follows: (1) oval shape; (2) smooth cortex $<3 \mathrm{~mm}$; (3) unchanged, clearly visible fat gate; and (4) central vascularity (Figure 1) [1,14]. The signs of PAUS-positive axillary lymph node were as follows: (1) oval or rounded shape; (2) local thickening of the cortex $>3 \mathrm{~mm}$; (3) dislocated gate; and (4) mixed or peripheral vascularity (Figure 2) [3,15,16].

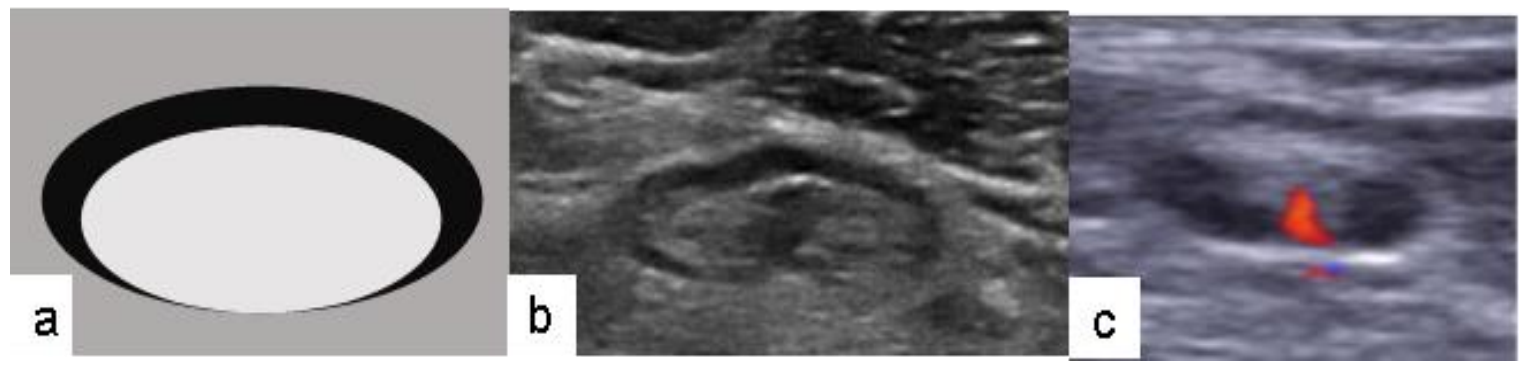

Figure 1. Lymph node with normal appearance: (a) schematic drawing; (b) signs of preoperative axillary ultrasound-negative lymph node (oval shape, smooth cortex, unchanged, clearly visible fat gate); (c) central vascularity.

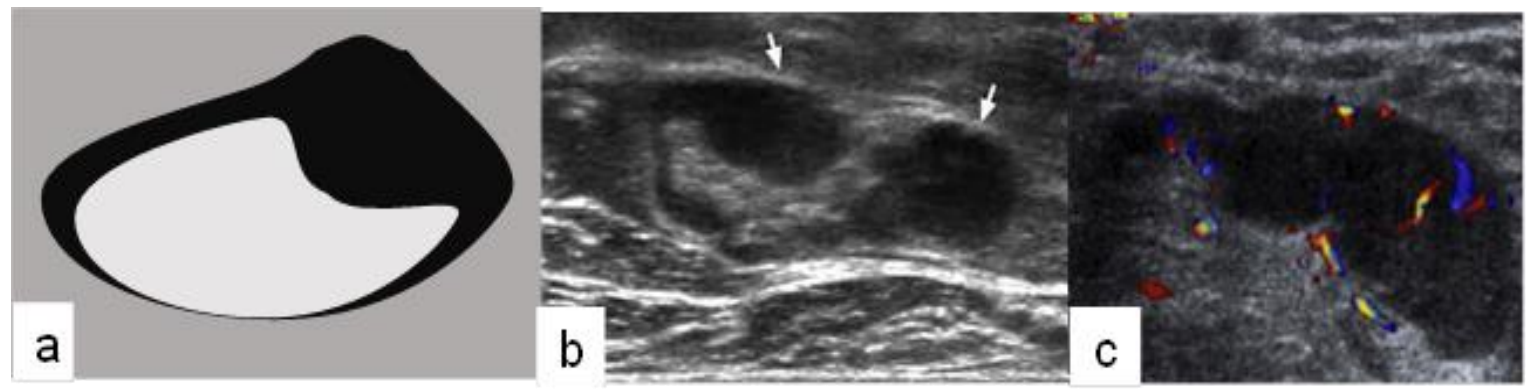

Figure 2. Suspicious lymph node: (a) schematic drawing; (b) signs of PAUS-positive lymph node (oval or rounded shape, local thickening of the cortex, dislocated gate); (c) mixed or peripheral vascularity.

During surgery, the location of the SLN was detected with a Crystal Probe automatic hand-held gamma detector. Surgically removed radioactive lymph nodes were subjected to pathological examination (hematoxylin and eosin staining and immunohistochemistry). According to the recommendations of the ACOSOG Z0011 study, after SLNB, if metastases were found only in one or two SLNs, axillary lymph node dissection (ALND) was not performed; if metastases were found in three and more sentinel lymph nodes (heavy nodal disease burden), ALND was performed [17]. If an SLN was not found, ALND was also performed. The following histopathological data were analyzed: histological tumor type, presence of non-invasive component (ca in situ), tumor size (pT), tumor grade (G), lymphovascular invasion $(\mathrm{LV})$, presence of estrogen (ER) or progesterone (PR) receptors, human epidermal growth factor (HER2) status, and lymph node $(\mathrm{N})$ status. Nodal metastasis was defined as the presence of macrometastasis $(>2.0 \mathrm{~mm})$ (node-positive); lymph nodes without tumor cells or with only isolated tumor cells $(<0.2 \mathrm{~mm})$ or with micrometastasis $(0.2-2 \mathrm{~mm})$ were considered negative (node-negative) [13,18-20]. The nodal disease burden was categorized as a limited nodal tumor burden (without or with 1 or 2 tumor-involved 
lymph nodes) and a heavy nodal tumor burden ( $\geq 3$ tumor-involved lymph nodes). PAUS data were compared with the results of histological examination.

\section{Statistical Analysis}

Statistical analysis was performed using IBM SPSS Statistics 25 package (IBM Corp. Released 2017. IBM SPSS Statistics for Windows, Version 25.0. Armonk, NY, USA: IBM Corp). Descriptive statistics methods were used to systemize the study data. The accuracy, sensitivity, specificity, positive-predictive value (PPV), and negative-predictive value (NPV) of the ultrasound examination were evaluated, and the estimates of these characteristics were given along with their $95 \%$ confidence intervals (CIs). The chi-square test for independence (homogeneity) was used to compare the effects of clinicopathological factors and the correlation of outcomes from PAUS and SLNB pathology. The Student $t$ test was used to compare continuous data with normal distribution. The observed differences and associations were considered statistically significant if $p<0.05$.

\section{Results}

The study analyzed 227 women aged 32 to 85 years, with a mean age of 59 years (SD, 11.83). The patients were divided into three groups according to age: $\leq 50$ years $(n=55,24.2 \%), 50-70$ years $(n=125$, $55.1 \%)$, and $>70$ years $(\mathrm{n}=47,20.7 \%)$. Women with pT1c breast cancer accounted for the largest proportion $(68.3 \%)$. Unifocal tumors were more prevalent $(\mathrm{n}=172,75.8 \%)$; tumor multifocality was documented in 55 cases $(24.2 \%)$. Infiltrative ductal carcinoma was the most common histological type $(74.0 \%)$. The non-invasive component was found in $33.0 \%$ of cases. The majority $(79.3 \%)$ of the tumors were of medium differentiation grade (G2). Lymphovascular invasion (LV1) was recorded in $60.8 \%$ of the cases, and $39.2 \%$ of the cases did not show lymphovascular invasion (LV0). Hormone-sensitive tumors were more common (ER(+) $88.1 \%$ and $\mathrm{PR}(+) 78.9 \%)$. Nearly two-thirds $(63.0 \%)$ of the tumors were HER2(0) and 37\%, HER2(1). Patients' demographic characteristics and tumor clinicopathological data by node-negative and node-positive groups are shown in Table 1.

On ultrasound, suspicious lymph nodes (PAUS-positive) were identified in 38 cases (16.7\%), and in the remaining 189 cases (83.3\%), axillary lymph nodes had normal appearance (PAUS-negative). During surgery, the SLN was found in $96.9 \%$ of the cases. Of these, additional lymphadenectomy (LMND) was performed in $3.2 \%$ of the cases because 3 SLNs were found and they all were node-positive. In 1.3\% of the cases, 4-6 SLNs were excised; metastases were found in 3 lymph nodes, and no ALND was performed. The SLN was not found in $3.1 \%$ of the cases, and these patients also underwent LMND (Figure 3). Of the all examined patients, 193 patients (85.0\%) were node-negative (5 cases of pN1mi); metastases were present in 34 cases (15.0\%). Metastases in $\leq 2$ lymph nodes were found in 23 cases $(10.1 \%)$; a heavy nodal burden ( $\geq 3$ positive nodes) was documented in 11 cases $(4.8 \%)$ (Figure 3$)$. The results of ultrasound and histological examination of axillary lymph nodes are displayed in Figure 4.

The specificity, accuracy, and NPV of ultrasound examination were found to be high, i.e., $89.6 \%$, $84.1 \%$, and $91.5 \%$, respectively; while the sensitivity was moderate being $52.9 \%$. In $\geq 3$ node-positive cases, the sensitivity of PAUS increased to $72.7 \%$; accuracy to $88.7 \%$; and NPV to $98.3 \%$. In total, false-negative results were recorded in $8.5 \%(n=16)$ of the cases; in the PAUS-negative group, false-negative results were found only in $1.6 \%(n=3)$ of the cases. Diagnostic discrimination of PAUS is shown in Table 2. 
Table 1. Patients' demographic and tumor clinicopathological characteristics by node-negative and node-positive groups.

\begin{tabular}{|c|c|c|c|c|}
\hline Parameter & $\begin{array}{c}\text { Total } \\
(\mathrm{n}=227)\end{array}$ & $\begin{array}{l}\text { Node-Negative } \\
\quad(n=193)\end{array}$ & $\begin{array}{l}\text { Node-Positive } \\
\quad(\mathrm{n}=34)\end{array}$ & $p$ Value \\
\hline Age, mean (SD), years & $59.55(11.83)$ & $59.88(11.93)$ & $57.65(11.21)$ & 0.311 \\
\hline $\begin{array}{l}\text { Age categories: } \\
\leq 50 \text { years } \\
50-70 \text { years } \\
>70 \text { years }\end{array}$ & $\begin{array}{c}55 \\
125 \\
47\end{array}$ & $\begin{array}{c}45(81.8) \\
106(84.8) \\
42(89.4)\end{array}$ & $\begin{array}{l}10(18.2) \\
19(15.2) \\
5(10.6)\end{array}$ & 0.565 \\
\hline $\begin{array}{c}\text { Findings on PAUS, n }(\%) \text { : } \\
\text { Negative } \\
\text { Positive }\end{array}$ & $\begin{array}{c}189 \\
38 \\
\end{array}$ & $\begin{array}{l}173(91.5) \\
20(52.6)\end{array}$ & $\begin{array}{c}16(8.5) \\
18(47.4)\end{array}$ & $<0.001$ \\
\hline $\begin{array}{c}\text { Number of focus, } \mathrm{n}(\%) \text { : } \\
\text { Unifocal } \\
\text { Multifocal }\end{array}$ & $\begin{array}{c}172 \\
55\end{array}$ & $\begin{array}{c}146(84.9) \\
47(85.5)\end{array}$ & $\begin{array}{c}26(15.1) \\
8(14.5)\end{array}$ & 0.556 \\
\hline $\begin{array}{c}\text { Histological subtype, n (\%): } \\
\text { Invasive ductal } \\
\text { Invasive lobular } \\
\text { Other }\end{array}$ & $\begin{array}{c}168 \\
19 \\
40\end{array}$ & $\begin{array}{l}143(85.1) \\
14(73.7) \\
36(90.0)\end{array}$ & $\begin{array}{l}25(14.9) \\
5(26.3) \\
4(10.0)\end{array}$ & 0.260 \\
\hline $\begin{array}{c}\text { Presence of non-invasive } \\
\text { component, } \mathrm{n}(\%) \text { : } \\
\text { ca in situ }(+) \\
\text { ca in situ }(-)\end{array}$ & $\begin{array}{c}75 \\
152\end{array}$ & $\begin{array}{c}64(85.3) \\
129(84.9)\end{array}$ & $\begin{array}{l}11(14.7) \\
23(15.1)\end{array}$ & 0.548 \\
\hline $\begin{array}{l}\text { Tumor size, } \mathrm{n}(\%) \text { : } \\
\text { pT1a } \\
\text { pT1b } \\
\text { pT1c }\end{array}$ & $\begin{array}{c}27 \\
45 \\
155\end{array}$ & $\begin{array}{c}26(96.3) \\
40(88.9) \\
127(81.9)\end{array}$ & $\begin{array}{c}1(3.7) \\
5(11.1) \\
28(18.1)\end{array}$ & 0.112 \\
\hline 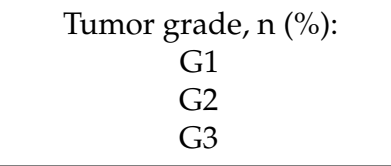 & $\begin{array}{c}23 \\
180 \\
24\end{array}$ & $\begin{array}{l}22(95.7) \\
152(84.4) \\
19(79.2)\end{array}$ & $\begin{array}{c}1(4.3) \\
28(15.6) \\
5(20.8)\end{array}$ & 0.255 \\
\hline $\begin{array}{l}\text { Lymphovascular invasion, } \mathrm{n} \\
\qquad \begin{array}{c}\text { (\%): } \\
\text { LV0 } \\
\text { LV1 }\end{array}\end{array}$ & $\begin{array}{c}89 \\
138\end{array}$ & $\begin{array}{l}89(100.0) \\
104(75.4)\end{array}$ & $\begin{array}{c}0(0.0) \\
34(24.6)\end{array}$ & $<0.001$ \\
\hline $\begin{array}{l}\text { HR status, } \mathrm{n}(\%) \text { : } \\
\text { ER negative } \\
\text { ER positive }\end{array}$ & $\begin{array}{c}27 \\
200 \\
\end{array}$ & $\begin{array}{c}25(92.6) \\
168(84.0)\end{array}$ & $\begin{array}{c}2(7.4) \\
32(16.0)\end{array}$ & 0.191 \\
\hline $\begin{array}{l}\text { PR negative } \\
\text { PR positive }\end{array}$ & $\begin{array}{c}48 \\
179\end{array}$ & $\begin{array}{c}41(85.4) \\
152(84.9)\end{array}$ & $\begin{array}{c}7(14.6) \\
27(15.1)\end{array}$ & 0.568 \\
\hline $\begin{array}{c}\text { HER2 status, } \mathrm{n}(\%) \text { : } \\
\text { HER2 }(0) \\
\text { HER2 }(1)\end{array}$ & $\begin{array}{c}143 \\
84\end{array}$ & $\begin{array}{l}116(81.1) \\
77(91.7)\end{array}$ & $\begin{array}{c}27(18.9) \\
7(8.3)\end{array}$ & 0.022 \\
\hline
\end{tabular}

Categorical data were compared with the chi-square test; continuous data, with the Student $t$ test. PAUS, preoperative axillary ultrasound; LV, lymphovascular invasion; HR, hormone receptor; ER, estrogen receptor; PR, progesterone receptor; HER2, human epidermal growth factor receptor 2. 


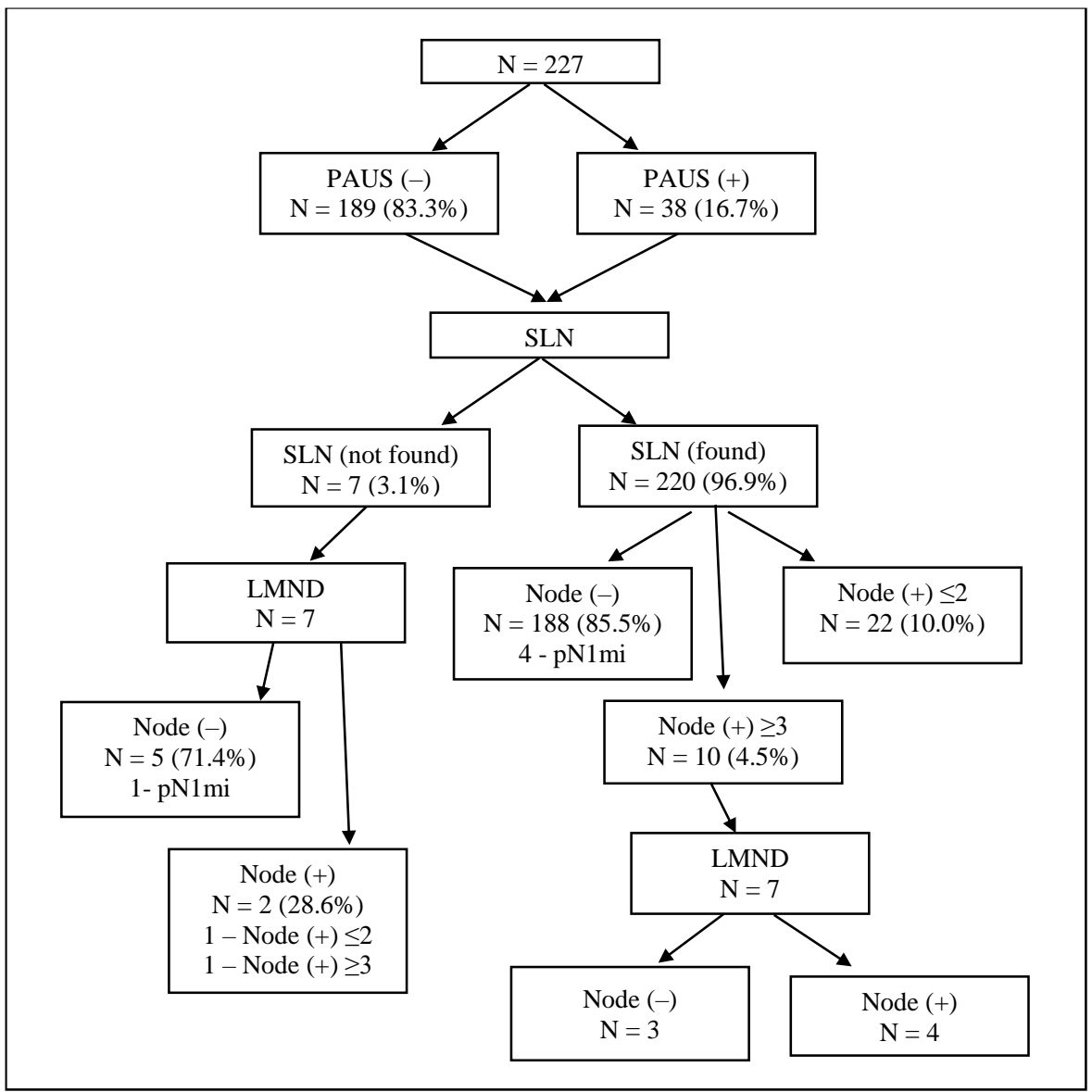

Figure 3. Flowchart of involvement of axillary lymph nodes in 227 patients. PAUS, preoperative axillary ultrasound; SLN, sentinel lymph node; LMND, lymphadenectomy.

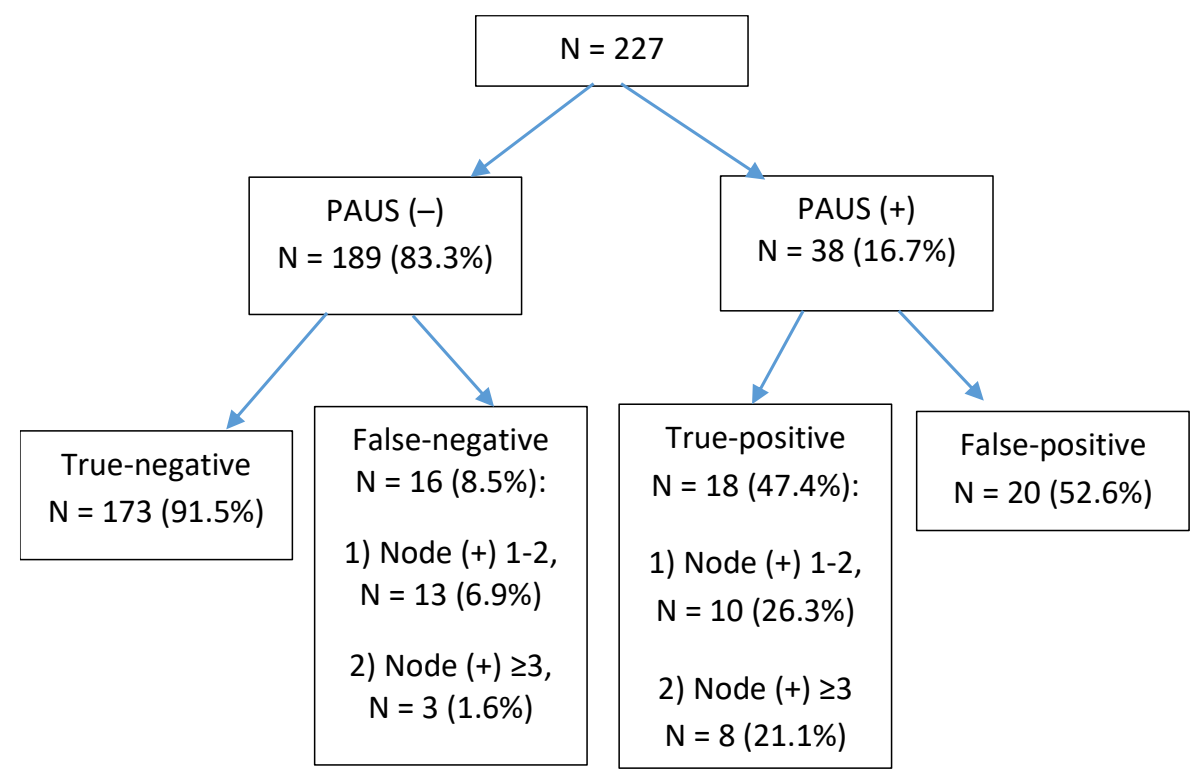

Figure 4. Flowchart of preoperative axillary ultrasound and histological examination findings in 227 patients. PAUS, preoperative axillary ultrasound. 
Table 2. Diagnostic discrimination of PAUS in patients with a limited nodal burden and a heavy nodal burden.

\begin{tabular}{|c|c|c|c|c|c|c|}
\hline PAUS & $\begin{array}{l}\text { Prevalence\% } \\
\text { (95\% CI) }\end{array}$ & $\begin{array}{c}\text { Accuracy } \\
\% \\
(95 \% \mathrm{CI})\end{array}$ & $\begin{array}{c}\text { Sensitivity } \\
\% \\
(95 \% \mathrm{CI})\end{array}$ & $\begin{array}{c}\text { Specificity } \\
\% \\
(95 \% \mathrm{CI})\end{array}$ & $\begin{array}{c}\text { Positive Predictive Value } \\
\% \\
(95 \% \mathrm{CI})\end{array}$ & $\begin{array}{c}\text { Negative Predictive Value } \\
\% \\
(95 \% \text { CI })\end{array}$ \\
\hline Total & $\begin{array}{c}15.0 \\
(9.1-20.9)\end{array}$ & $\begin{array}{c}84.1 \\
(78.1-90.2)\end{array}$ & $\begin{array}{c}52.9 \\
(31.5-74.3)\end{array}$ & $\begin{array}{c}89.6 \\
(84.2-95.1)\end{array}$ & $\begin{array}{c}47.4 \\
(27.1-67.6)\end{array}$ & $\begin{array}{c}91.5 \\
(86.5-96.6)\end{array}$ \\
\hline$\geq 3$ node + & $\begin{array}{c}5.4 \\
(1.4-9.3)\end{array}$ & $\begin{array}{c}88.7 \\
(83.2-94.3)\end{array}$ & $\begin{array}{c}72.7 \\
(39.2-106.3)\end{array}$ & $\begin{array}{c}89.6 \\
(84.2-95.1)\end{array}$ & $\begin{array}{c}28.6 \\
(7.2-49.9)\end{array}$ & $\begin{array}{c}98.3 \\
(95.9-100.7)\end{array}$ \\
\hline
\end{tabular}

Histopathological tumor data and true-negative and false-negative results were analyzed. The results of ultrasound and pathological examination significantly differed between patients without lymphovascular invasion (LV0) and those who had lymphovascular invasion (LV1). Paired comparison showed the true-negative rate was statistically significantly different between the LV0 and LV1 groups (91\% vs. $66.7 \%, p<0.05)$. False-negative and true-positive results were documented only in the LV1 group, and the false-positive rate was the same in both groups ( $9 \%$ vs. $8.7 \%$ in the LV0 and LV1 groups, respectively; $p>0.05)$. In the LV0 group $(n=89)$, all patients were node-negative ( $91 \%$ true-negative and $9 \%$ false-positive).

Moreover, the results of ultrasound and pathological examination were significantly different between patients without the expression of HER2 (HER2(0)) and those with weakly or strongly expressed HER2 (HER2(1)) ( $p=0.024)$. Paired comparisons showed that the false-negative rate was statistically significantly different between the HER2(0) and HER2(1) groups (10.5\% vs. $1.2 \%, p<0.05)$. True-negative, true-positive, and false-positive rates were similar in both the HER2(0) and HER2(1) groups $(74.8 \%$ vs. $78.6 \%, 8.4 \%$ vs. $7.1 \%, 6.3 \%$ vs. $13.1 \%$, respectively; $p>0.05)$.

Evaluation of other characteristics such as tumor size, multifocality, histological type, presence of non-invasive component, differentiation grade, estrogen/progestin receptor status, and patients' age showed patients' groups to be homogenous.

\section{Discussion}

Early stage breast cancer is defined as disease confined to the breast with or without regional lymph node involvement and the absence of distant metastatic disease [21]. The role of SLNB is controversial. According to the literature, approximately $60 \%$ to $85 \%$ of early breast cancer cases are node negative, thus would not benefit from SLNB [1,2,5,22-26]. In our study, $85.0 \%$ of the cases were node-negative, and axillary surgical interventions were unnecessary. Metastatic lymph nodes were detected only in $15.0 \%$ of the cases, and it might be caused by the fact that we included women with tumors of small size (pT1) to this study. Several studies have reported that the frequency of axillary lymph node metastases depends on tumor size, and it varies between $10 \%$ and $26 \%$ in pT1 tumors [25-28].

The SLN was found in $96.9 \%$ of the cases; of them, additional LMND was performed in $3.2 \%$ of the cases. In additionally removed lymph nodes, metastases were found in $57.1 \%$ of the cases, while in the remaining cases, additionally removed nodes were node-negative. According to other studies in the literature, ALND followed by positive results for metastasis at SLNB showed the absence of metastasis of $38 \%$ to $67 \%$ in the remaining lymph nodes [29-31].

Based on literature data, surgeons identify an SLN in $79 \%$ to $98 \%$ of cases, and in $2-21 \%$ of cases, an SLN is not detected [4,32-34]. Such varying results depend on different surgeons' experience [33,34]. In our study, the SLN was not found in 3.1\% of the cases. These patients also underwent LMND, and $71.4 \%$ of the cases were node-negative, thus did not benefit from surgical intervention.

One of the objectives of this study was to determine the NPV of PAUS. The reported NPV of PAUS for predicting negative nodal status varies widely in the literature, from 68 to $98 \%$ [15,16,23,35-38]. In our study, the NPV was very high $(91.5 \%, 95 \% \mathrm{CI}, 86.5 \%$ to $96.6 \%)$, and it could be due to small tumor size (pT1), therefore, leading to a lower metastasis incidence. Accordingly, negative axillary ultrasound excluded axillary metastatic disease in $91.5 \%$ of the patients. These data suggest that 
negative axillary ultrasound may replace SLNB in the majority of cases when the tumor size is small. In our study, the accuracy of the ultrasound examination was also quite high (84.1\%). In other studies, it varied from $66 \%$ to $90.2 \%[2,8,10,11,35,39]$.

Most previous studies have focused on PAUS ability to predict any nodal involvement $[2,7,8,36$, 39,40 ]. Some studies examined ultrasound ability to discriminate between minimal and heavy axillary metastatic burden. In all these studies, the NPV and the accuracy of the PAUS increased to 86-98.4\% and $81.2-98.5 \%$ in cases with a heavy nodal burden $[10,11,16,35]$. In the current study, the NPV and the accuracy of PAUS in detecting a heavy nodal burden increased to $98.3 \%$ and to $88.7 \%$, respectively.

Our additional objective was to examine patients' and tumor characteristics associated with false-negative results of PAUS. Our study showed that in the PAUS-negative group, a heavy nodal burden was found only in $1.6 \%$ of the cases (false-negative rate). Patients' and tumor characteristics associated with false-negative axillary ultrasound in several studies are shown in Table 3 . The study by Jackson et al. showed a false-negative rate of PAUS being 4\% (95\% CI, 2-6\%) for detecting $\geq 3$ nodal metastasis [10]. In this study, cases with a different tumor size (pT1, pT2, pT3, pT4) were included. The false-negative rate in the pT2-pT4 group was $8.2 \%$, and in the pT1 group, it was $1.7 \%$, being very similar to the rate in our study [10]. Several studies have demonstrated that larger tumor sizes were more often associated with false-negative results of ultrasound [2,11,41-43]. These results show that smaller tumors are generally associated with a lower likelihood of nodal positivity, so a lower false-negative rate could be expected with lower pathologic T size.

Table 3. Data of several studies: associations between clinicopathological factors and false-negative rate of PAUS.

\begin{tabular}{|c|c|c|c|}
\hline Author & PAUS-Negative & False-Negative Rate & Feature, $p$-Value \\
\hline Johnson et al., 2011 & $\mathrm{~N}=155$ & $29 \%$ (overall) & $\begin{array}{l}\text { Size of tumor }(p=0.02) \\
\text { Lymphovascular invasion }(p<0.001) \\
\text { Histological type of tumor }(p<0.001)\end{array}$ \\
\hline Stachs et al., 2013 & $\mathrm{~N}=378$ & $18.5 \%$ (overall) & $\begin{array}{c}\text { Tumor size }(p<0.001) \\
\text { tumor grade }(p=0.005), \text { lymphovascular } \\
\text { invasion }(p<0.001) \\
\text { ER status }(p=0.024) \\
\text { PR status }(p=0.014) \\
\text { HER2 status }(p=0.007) \\
\text { Ki-67 proliferation index }(p<0.001)\end{array}$ \\
\hline Meretoja et al., 2014 & - & - & $\begin{array}{c}\text { Tumor size }(p<0.001) \text {, multifocality }(p< \\
0.001) \\
\text { lymphovascular invasion }(p<0.001) \\
\text { palpability of the primary tumor }(p<0.001)\end{array}$ \\
\hline Nwaogu et al., 2015 & $\mathrm{~N}=118$ & $21 \%$ (overall) & $\begin{array}{c}\text { Tumor size }(p<0.01) \\
\text { lymphovascular invasion }(p<0.0001)\end{array}$ \\
\hline Jackson et al., 2015 & $\mathrm{~N}=400$ & $\begin{array}{c}14 \% \text { (overall) } \\
4 \% \text { (for detecting } \geq 3 \\
\text { nodal metastasis) }\end{array}$ & $\begin{array}{l}\text { Tumor size }(p=0.005) \\
\text { histological tumor type }(p=0.004)\end{array}$ \\
\hline Artmoniene et al., 2019 & $\mathrm{~N}=581$ & $18.7 \%$ & $\begin{array}{l}\text { Tumor size }(p<0.0001) \\
\text { tumor grade }(p=0.034), \text { lymphovascular } \\
\text { invasion }(p<0.0001) \text {, patient age }(p=0.006)\end{array}$ \\
\hline Current study & $N=189$ & $\begin{array}{c}8.5 \% \text { (overall) } \\
1.6 \% \text { (for detecting } \geq 3 \\
\text { nodal metastasis) }\end{array}$ & Lymphovascular invasion $(p<0.0001)$ \\
\hline
\end{tabular}

Two studies identified a relationship between false-negative PAUS and histological tumor type. In the false-negative PAUS group, lobular carcinoma was more frequently diagnosed than other types of carcinoma [10,42]. In our study, we did not find any association between false-negative PAUS rate and tumor histological type. It might be caused by a small number of patients with lobular carcinoma in our study.

Some previous studies have reported associations between higher tumor grade (G3) and an increased likelihood of false-negative PAUS results $[2,11]$. However, we did not find any difference in the false-negative rate depending on tumor grade. 
The study by Meretoja et al. demonstrated that false-negative axillary ultrasound was more frequently documented in patients who had multifocal tumor versus patients who had unifocal tumor [43]. In our study, there was no significant difference in the false-negative PAUS rate comparing patients with multifocal and unifocal disease.

Several previous studies have shown an association between lymphovascular invasion in the breast and false-negative results of PAUS [2,11,41-43]. In the study by Johnson et al., the false-negative group was more likely to have lymphovascular invasion in the breast than the true-negative one $(5 \%$ vs. $31 \%, p<0.001$ ) [42]. The study by Nwaogu et al. showed that lymphovascular invasion was also more likely to occur in the false-negative group compared with the true-negative group ( $44 \%$ vs. $8 \%, p<0.0001$ ) [41]. The study by Artmoniene et al. demonstrated that in cases with LV1, the false-negative rate of PAUS was greater (V1 54.6\% and L1 98.3\%), and the true-negative rate of PAUS was lower (V1 23.5\% and L1 29.6\%) $(p<0.0001)$ [11].

We found significant differences in PAUS results between patients without lymphovascular invasion (LV0) and with lymphovascular invasion (LV1). The true-negative rate of PAUS was significantly different between the LV0 and LV1 groups. False-negative results of PAUS were recorded only in the LV1 group. Moreover, we showed that in the LV0 group $(n=89)$, all patients were node-negative (91\% of true-negative and $9 \%$ of false-positive); therefore, we can rely on PAUS examination that axillary lymph nodes are intact.

Our study also revealed significant differences in PAUS results between patients without and with HER2 expression. There was a significant difference in the false-negative rate of PAUS comparing the HER2(0) and HER2(1) groups $(10.5 \%$ and $1.2 \%$, respectively; $p<0.05)$. In the study by Stachs et al., the false-negative PAUS rate was also more frequently found in the HER2(0) than the HER2(1) group (56\% vs. $18.8 \%, p=0.007)$. Therefore, the assessment of axillary ultrasound may be less accurate in this subset, and a negative result should be interpreted with caution. Other features had no impact on the false-negative rate of PAUS.

Our study had some limitations to be mentioned. First, the study population included a relatively small number of patients from a single institution. Second, in this study, ultrasound evaluation was performed by one radiologist who had 10-year work experience. In the future, it would be interesting to include more institutions and more radiologists with different work experience and then to compare the obtained results. PAUS is a valuable and cost-effective imaging tool that could replace SLNB in majority of cases when the tumor size is small.

\section{Conclusions}

Negative axillary ultrasound excluded axillary metastatic disease in $91.5 \%$ of the patients; therefore, sentinel lymph node biopsy itself represented surgical over-treatment in these patients. PAUS had an accuracy of $88.7 \%$ in detecting a heavy nodal disease burden. In the LV0 group, PAUS results were found to be reliable and SLNB could be avoided. The probability of false-negative PAUS rate was higher in patients without HER2 expression; therefore, negative PAUS findings in patients with HER2(0) should be interpreted cautiously.

Author Contributions: Conceptualization, A.B. and D.Č.; methodology, V.V.; software, R.P.; formal analysis, L.P.; data curation, M.B. and D.K.; writing—original draft preparation, D.R.; writing—review and editing, E.J. All authors have read and agreed to the published version of the manuscript.

Funding: This research received no external funding.

Conflicts of Interest: The authors declare no conflict of interest.

\section{References}

1. Maxwell, F.; Mellon, C.D.M.; Bricout, M.; Cauderlier, E.; Chapelier, M.; Albiter, M.; Bourrier, P.; Espié, M.; de Kerviler, M.; de Bazelaire, C. Diagnostic strategy for the assessment of axillary lymph node status in breast cancer. Diagn. Interv. Imaging 2015, 96, 1089-1101. [CrossRef] [PubMed] 
2. Stachs, A.; Göde, K.; Hartmann, S.; Stengel, B.; Nierling, U.; Dieterich, M.; Reimer, T.; Gerber, B. Accuracy of axillary ultrasound in preoperative nodal staging of breast cancer-Size of metastases as limiting factor. Springerplus 2013, 2, 1-9. [CrossRef] [PubMed]

3. Dihge, L. Predictors of Lymph Node Metastasis in Primary Breast Cancer Risk Models for Tailored Axillary Management. Ph.D. Thesis, Lund University, Lund, Sweden, 2018.

4. Zahoor, S.; Haji, A.; Battoo, A.; Qurieshi, M.; Mir, W.; Shah, M. Sentinel lymph node biopsy in breast cancer: A clinical review and update. J. Breast Cancer 2017, 20, 217-227. [CrossRef] [PubMed]

5. Barco, I.; Chabrera, C.; García-Fernández, A.; Fraile, M.; González, S.; Canales, L.; Lain, J.M.; González, C.; Vidal, M.C.; Vallejo, E.; et al. Role of axillary ultrasound, magnetic resonance imaging, and ultrasound-guided fine-needle aspiration biopsy in the preoperative triage of breast cancer patients. Clin. Transl. Oncol. 2017. [CrossRef] [PubMed]

6. Avisar, E.; Ozmen, T. Management of the positive axilla in 2017. Breast Cancer Res. Treat. 2017. [CrossRef] [PubMed]

7. Jozsa, F.; Ahmed, M.; Baker, R.; Douek, M. Is sentinel node biopsy necessary in the radiologically negative axilla in breast cancer? Breast Cancer Res. Treat. 2019, 177, 1-4. [CrossRef] [PubMed]

8. Gipponi, M.; Fregatti, P.; Garlaschi, A.; Murelli, F.; Margarino, C.; Depaoli, F.; Baccini, P.; Gallo, M.; Friedman, D. Axillary ultrasound and Fine-Needle Aspiration Cytology in the preoperative staging of axillary node metastasis in breast cancer patients. Breast 2016, 30, 146-150. [CrossRef]

9. NCT02167490. Sentinel Node vs. Observation after Axillary Ultra-souND. Available online: Https: //clinicaltrials.gov/show/nct02167490 (accessed on 6 October 2019).

10. Jackson, R.S.; Mylander, C.; Rosman, M.; Andrade, R.; Sawyer, K.; Sanders, P.; Tafra, L. Normal axillary ultrasound excludes heavy nodal disease burden in patients with breast cancer. Ann. Surg. Oncol. 2015, 22, 3289-3295. [CrossRef]

11. Artmoniene, D. Breast cancer: The accuracy of the Paus in detecting pN2 and factors that lead to the trueand false-negative results. Biomed. J. Sci. Tech. Res. 2019, 12, 1-9. [CrossRef]

12. Gentilini, O.; Botteri, E.; Dadda, P.; Sangalli, C.; Boccardo, C.; Peradze, N.; Ghisini, R.; Galimberti, V.; Veronesi, P.; Luini, A.; et al. Physical function of the upper limb after breast cancer surgery. Results from the SOUND (Sentinel node vs. Observation after axillary Ultra-souND) trial. Eur. J. Surg. Oncol. 2016, 42, 685-689. [CrossRef]

13. Reimer, T.; Stachs, A.; Nekljudova, V.; Loibl, S.; Hartmann, S.; Wolter, K.; Hildebrandt, G.; Gerber, B. Restricted axillary staging in clinically and sonographically node-negative early invasive breast cancer (C/IT1-2) in the context of breast conserving therapy: First results following commencement of the intergroup-sentinel-mamma (INSEMA) trial. Geburtshilfe Frauenheilkd. 2017, 77, 149-157. [CrossRef] [PubMed]

14. Ecanow, J.; Abe, H.; Newstead, G.M.; Ecanow, D.B.; Jeske, J.M. Axillary Staging of Breast Cancer: What the Radiologist Should Know. Radiographics 2013, 33, 1589-1612. [CrossRef]

15. Dihge, L.; Grabau, D.A.; Rasmussen, R.W.; Bendahl, P.O.; Rydén, L. The accuracy of preoperative axillary nodal staging in primary breast cancer by ultrasound is modified by nodal metastatic load and tumor biology. Acta Oncol. (Madr) 2016, 55, 976-982. [CrossRef] [PubMed]

16. van Nijnatten, T.J.A.; Ploumen, E.H.; Schipper, R.J.; Goorts, B.; Andriessen, E.H.; Vanwetswinkel, S.; Schavemaker, M.; Nelemans, P.; de Vries, B.; Beets-Tan, R.G.H.; et al. Routine use of standard breast MRI compared to axillary ultrasound for differentiating between no, limited and advanced axillary nodal disease in newly diagnosed breast cancer patients. Eur. J. Radiol. 2016, 85, 2288-2294. [CrossRef] [PubMed]

17. Jung, J.; Han, W.; Lee, E.S.; Jung, S.-Y.; Han, J.H.; Noh, D.-Y.; Kim, Y.; Choi, H.J.; Lee, J.E.; Nam, S.J.; et al. Retrospectively validating the results of the ACOSOG Z0011 trial in a large Asian Z0011-eligible cohort. Breast Cancer Res. Treat. 2019. [CrossRef] [PubMed]

18. Naidoo, K.; Pinder, S.E. Micro- and macro-metastasis in the axillary lymph node: A review. Surgeon 2017, 15, 76-82. [CrossRef] [PubMed]

19. Zhu, Y.; Zhou, W.; Jia, X.H.; Huang, O.; Zhan, W.W. Preoperative axillary ultrasound in the selection of patients with a heavy axillary tumor burden in early-stage breast cancer: What leads to false-positive results? J. Ultrasound Med. 2018, 1357-1365. [CrossRef] [PubMed] 
20. Galimberti, V.; Cole, B.F.; Zurrida, S.; Viale, G.; Luini, A.; Veronesi, P.; Baratella, P.; Chifu, C.; Sargenti, M.; Intra, M.; et al. Axillary dissection versus no axillary dissection in patients with sentinel-node micrometastases (IBCSG 23-01): A phase 3 randomised controlled trial. Lancet Oncol. 2013, 14, 297-305. [CrossRef]

21. Early stage breast cancer. Union for International Cancer Control. 2014 Review of Cancer Medicines on the WHO List of Essential Medicines. Available online: https://www.who.int/selection_medicines/committees/ expert/20/applications/EarlyStageBreast.pdf?ua=1 (accessed on 6 October 2019).

22. Qiu, S.Q.; Zeng, H.C.; Zhang, F.; Chen, C.; Huang, W.-H.; Pleijhuis, R.G.; Wu, J.-D.; van Dam, G.M.; Zhang, G.-J. A nomogram to predict the probability of axillary lymph node metastasis in early breast cancer patients with positive axillary ultrasound. Sci. Rep. 2016, 6, 1-12. [CrossRef]

23. Schipper, R.J.; van Roozendaal, L.M.; de Vries, B.; Pijnappel, R.M.; Beets-Tan, R.G.H.; Lobbes, M.B.I.; Smidtbe, M.L. Axillary ultrasound for preoperative nodal staging in breast cancer patients: Is it of added value? Breast 2013, 22, 1108-1113. [CrossRef]

24. Chikarmane, S.A.; Tirumani, S.H.; Howard, S.A.; Jagannathan, J.P.; Dipiro, P.J. Metastatic patterns of breast cancer subtypes: What radiologists should know in the era of personalized cancer medicine. Clin. Radiol. 2015, 70, 1-10. [CrossRef]

25. Orang, E.; Marzony, E.T.; Afsharfard, A. Predictive role of tumor size in breast cancer with axillary lymph node involvement-Can size of primary tumor be used to omit an unnecessary axillary lymph node dissection? Asian Pacific. J. Cancer Prev. 2013, 14, 717-722. [CrossRef] [PubMed]

26. Zhao, Y.X.; Liu, Y.R.; Xie, S.; Jiang, Y.Z.; Shao, Z.M. A nomogram predicting lymph node metastasis in $\mathrm{t} 1$ breast cancer based on the surveillance, epidemiology, and end results program. J. Cancer 2019, 10, 2443-2449. [CrossRef] [PubMed]

27. Bevilacqua, J.L.B.; Kattan, M.W.; Fey, J.V.; Cody, H.S.; Borgen, P.I.; Van Zee, K.J. Doctor, what are my chances of having a positive sentinel node? A validated nomogram for risk estimation. J. Clin. Oncol. 2007, 25, 3670-3679. [CrossRef] [PubMed]

28. Abner, A.L.; Collins, L.; Peiro, G.; Recht, A.; Come, S.; Shulman, L.N.; Barbara Silver, B.; Asa Nixon, A.; Harris, J.R.; Schnitt, S.J.; et al. Correlation of tumor size and axillary lymph node involvement with prognosis in patients with $\mathrm{T} 1$ breast carcinoma. Cancer 1998, 83, 2502-2508. [CrossRef]

29. Kim, G.R.; Choi, J.S.; Han, B.K.; Lee, J.E.; Nam, S.J.; Ko, E.Y.; Ko, E.S.; Lee, S.K. Preoperative axillary US in early-stage breast cancer: Potential to prevent unnecessary axillary lymph node dissection. Radiology 2018, 288, 55-63. [CrossRef]

30. Nath, J.; Sami, N.; Massey, J.; Donnelly, J.; Corder, A.P. Selection for axillary clearance in breast cancer (ultrasound negative, sentinel node positive patients have low rates of further metastases). Eur. J. Surg. Oncol. 2013, 39, 450-454. [CrossRef]

31. del Riego, J.; Diaz-Ruiz, M.J.; Teixidó, M.; Ribé, J.; Vilagran, M.; Canales, L.; Sentís, M.; de Mama Vallès-Osona-Bages, G. The impact of preoperative axillary ultrasonography in T1 breast tumours. Eur. Radiol. 2016, 26, 1073-1081. [CrossRef]

32. Gadd, M.; Kuhn, J.; Harlow, S.; Beitsch, P. The sentinel node in breast cancer-A multicenter validation study. N. Engl. J. Med. 1998, 339, 941-946.

33. Cox, C.E.; Salud, C.J.; Cantor, A.; Bass, S.S.; Peltz, E.S.; Ebert, M.D.; Nguyen, K.; Reintgen, D.S. Learning curves for breast cancer sentinel lymph node mapping based on surgical volume analysis. J. Am. Coll. Surg. 2001, 193, 593-600. [CrossRef]

34. James, T.A.; Coffman, A.R.; Chagpar, A.B.; Boughey, J.C.; Klimberg, V.S.; Morrow, M.; Giuliano, A.E.; Harlow, S.P. Troubleshooting sentinel lymph node biopsy in breast cancer surgery. Ann. Surg. Oncol. 2016, 23, 3459-3466. [CrossRef]

35. Abe, H.; Schacht, D.; Sennett, C.A.; Newstead, G.M.; Schmidt, R.A. Utility of preoperative ultrasound for predicting $\mathrm{pN} 2$ or higher stage axillary lymph node involvement in patients with newly diagnosed breast cancer. Am. J. Roentgenol. 2013, 200, 696-702. [CrossRef] [PubMed]

36. Ameri, B.; Kanesa-Thasan, R.; Abu-Khalaf, M.M.; Berger, A.C.; Eisenberg, T.; Lazar, A.; Sevrukov, A.; Tsangaris, T.N.; Wasti, N.; Wilkes, A.; et al. Negative predictive value of ipsilateral axillary ultrasound in the pre-operative assessment of invasive breast cancer. J. Clin. Oncol. 2017, 35, e12080. [CrossRef]

37. Verheuvel, N.C.; Voogd, A.C.; Tjan-Heijnen, V.C.G.; Roumen, R.M.H. Potential impact of application of Z0011 derived criteria to omit axillary lymph node dissection in node positive breast cancer patients. Eur. J. Surg. Oncol. 2016, 42, 1162-1168. [CrossRef] [PubMed] 
38. Moorman, A.M.; Bourez, R.L.J.H.; Heijmans, H.J.; Kouwenhoven, E.A. Axillary ultrasonography in breast cancer patients helps in identifying patients preoperatively with limited disease of the axilla. Ann. Surg. Oncol. 2014, 21, 2904-2910. [CrossRef] [PubMed]

39. Soltani, E.; Rad, M.P.; Aghaei, M.A.; Ghaffarzadegan, K.; Memar, B.; Jangjoo, A.; Omranipour, R. Could Using of Ultrasonic Grading for Axillary Lymph Nodes Improve Management of Early Stage Breast Cancer? Clin. Oncol. 2018, 3, 1486.

40. Ertan, K.; Linsler, C.; di Liberto, A.; Fang Ong, M.; Solomayer, E.; Endrikat, J. Axillary ultrasound for breast cancer staging: An attempt to identify clinical/histopathological factors impacting diagnostic performance. Breast Cancer Basic Clin. Res. 2013, 7, 35-40. [CrossRef]

41. Nwaogu, I.Y.; Yan, Y.; Appleton, C.M.; Cyr, A.E.; Margenthaler, J.A. Predictors of false negative axillary ultrasound in breast cancer. J. Surg. Res. 2015, 198, 351-354. [CrossRef]

42. Johnson, S.; Brown, S.; Porter, G.; Steel, J.; Paisley, K.; Watkins, R.; Holgate, C. Staging primary breast cancer. Are there tumour pathological features that correlate with a false-negative axillary ultrasound? Clin. Radiol. 2011, 66, 497-499. [CrossRef]

43. Meretoja, T.J.; Heikkilä, P.S.; Mansfield, A.S.; Cserni, G.; Ambrozay, E.; Boross, G.; Zgajnar, J.; Perhavec, A.; Gazic, B.; Arisio, R.; et al. A predictive tool to estimate the risk of axillary metastases in breast cancer patients with negative axillary ultrasound. Ann. Surg. Oncol. 2014, 21, 2229-2236. [CrossRef]

(C) 2020 by the authors. Licensee MDPI, Basel, Switzerland. This article is an open access article distributed under the terms and conditions of the Creative Commons Attribution (CC BY) license (http://creativecommons.org/licenses/by/4.0/). 